\title{
Analyst Coverage And The Diversification Discount
}

\author{
Ronald W. Best, (E-mail: rbest@westga.edu), State University of West Georgia
}

Charles W. Hodges, (E-mail: chodges@westga.edu), State University of West Georgia

Bing-Xuan Lin, (E-mail: blin@uri.edu), University of Rhode Island

\begin{abstract}
We use financial analyst coverage as a measure of information asymmetry to examine excess firm values associated with single-and multi-segment firms. We explicitly examine whether differences in analyst coverage can explain the diversification discount. We find that information asymmetry plays a major role in the valuation of companies and explains a large portion of the diversification discount. However, a significant diversification discount remains after controlling for the effects of analyst coverage.
\end{abstract}

\subsection{Introduction}

$M$

yers and Majluf (1984) show that in the presence of high information asymmetry between the firm and market, firms will forego positive NPV projects rather than go to the external capital market to finance projects. Thus, a major hypothesized benefit of diversification is the creation of internal capital markets. Diversification should create internal capital markets with lower levels of information asymmetry that allow firms to channel resources to the correct segments and reduce the under-investment problem.

Most empirical studies, however, conclude that on average diversification is a value decreasing activity (e.g., Berger and Ofek (1995), Servaes (1996), Lang and Stulz (1994)). Further, corporate refocusing has been found to increase the value of the firm and has been interpreted by some as evidence that firms were trying to undo previous mistakes of merger and diversification (e.g., Comment and Jarrell (1995) and Lane, Vikas, and Ranjini (1997)). Consequently, a body of literature on the inefficiency of internal capital markets has recently developed in order to explain the "diversification discount" (e.g., Shin and Stulz, (1998); Wulf, (1999); Rajan, Servaes, and Zingales (2000)).

While there is strong empirical evidence that diversified firms sell at a discount to single segment firms, there is less empirical as to whether this discount should exist. For example, several studies report positive market reactions to unrelated diversifying acquisitions in different time periods (e.g., Matsusaka (1993), Schipper and Thompson (1983), Hubbard and Palia (1999), Hyland (1997)). Other studies show that the risk-adjusted stock performance of multi-segment firms is at least equal to the returns on single segment firms (Graham, Lemmon, and Wolf, (1999) and Lamont and Polk (1999)).

Given the above information, the search for the source of the diversification discount has moved further afield. Much of the research asks how much of a discount, if any, is left after controlling for differences in the characteristics of diversifying and non-diversifying firms. Part of this research considers the possibility that information asymmetries may be greater for multi-segment firms that for single segment firms. Nanda and Narayanan (1999) formally develop an asymmetric information related model for divestitures that assumes that the market can observe the aggregate cash flows of the firm but not the individual divisional cash flows, resulting in misvaluation of the firm's securities. Krishnaswami and Subramaniam (1999) find that firms that engage in spin-offs have higher levels of information asymmetry compared to their industry and size matched counterparts and the

Readers with comments or questions are encouraged to contact the authors via email. 
information problems decrease significantly after a spin-off. They argue the size of gains around spin-offs is positively related to the pre-spinoff degree of information asymmetry. Hadlock, Ryngaert and Thomas (1998) examine a "transparency hypothesis" that suggests that diversified firms may be harder to value (less transparent) than focused firms. They suggest accounting figures reported for focused firms are more informative than those for diversified firms due to the aggregate nature of diversified firms' accounting reports. Consequently, asymmetric information problems would be more severe for diversified firms relative to focused firms. In a related vein, Dunn and Nathan (1998) show that as the level of a company's total diversification increases, analysts are less accurate in their earnings forecasts and have more inter-analyst disagreement. Similarly, Lamont and Polk (1999) provide evidence that conglomerate firms have higher required returns and that this can account for approximately one-third of the empirically observed diversification discount.

This paper explicitly considers the issue of the amount of the diversification discount after controlling for the difference in information asymmetry between single- and multi-segment firms. In this paper, we use coverage of the firm by financial analysts as a measure of a firm's degree of information asymmetry. We then examine whether differences in analyst coverage help explain the diversification discount. Our results, which cover the period of 1989-1998, indicate that analyst coverage plays a major role in explaining the valuation of firms. Both single- and multi-segment firms not covered by financial analysts have significantly smaller excess values than firms covered by analysts. Further, regression tests show that the multi-segment discount coefficient remains significant, but is reduced by approximately half when analyst coverage is introduced in the analysis.

\subsection{Sample Selection and Data Description}

FASB No.14 and SEC Regulation S-K require firms to report segment information for fiscal years ending after December 5, 1977. Firms must report audited footnote information for segments whose sales, assets, or profits exceed 10 percent of consolidated totals. The Compustat Industry Segment (CIS) database reports the number of different business segments, up to a maximum of 10, defined by the firm under FASB No. 14. Additionally segment information for all Compustat firms other than utility subsidiaries is recorded.

We collect the 1989-1998 data for all firms on the CIS database and use the method suggested by Berger and Ofek (1995) to complete the data selection process. To be included in the sample, firms shall have no segments in utility segments (SIC code 4000 - 4999) and financial segment (SIC code 6000 - 6999). Firms must have sales greater than twenty million dollars to be included in the sample. Because some multi-divisional firms sometimes do not fully allocate total firm sales to the segments, occasionally we will see some major differences between total firm sales and the sum of segment sales. To reduce the noise caused by such inconsistency, we further require that the sum of segment sales should be within one percent of total sales of the firm. After the above restrictions, we have 38312 segment observations.

Following Berger and Ofek (1995), to examine whether diversification enhances or decreases corporate value, we measure the percentage difference between a firm's total value and the sum of imputed values for its segments as a stand-alone entity. Mathematically, Extra value $=\ln (V / I(V))$, where $V$ is the firm's total capital defined as market value of common equity plus book value of debt, and $I(V)$ is the imputed value of the sum of a firm's seg-

ments as stand-alone entity. $I(V)=\sum_{i=1}^{n} A I_{i} \times\left(I n d_{i}(V / A I)_{m f}\right)$, where $A I_{i}$ is the segment $I$ 's sale in that year, and

$\operatorname{Ind}_{i}(V / A I)_{m f}$ is the industry median ratio of the total capital to sales. It is based on the narrowest SIC grouping that includes at least five single-line businesses with at least $\$ 20$ million of sales and sufficient data for computing the ratios. The imputed value of $53.3 \%$ of all segments are based on 4 digit SIC code industries, $28.9 \%$ on 3 digit industries, $14.3 \%$ on 2 digit industries and 3.2\% are unavailable. To further remove noise from the analysis, we also exclude observations if the calculated extra value is above 1.386 or below -1.386 (actual values either more than four times the imputed value or less than one-fourth imputed). Berger and Ofek (1995) apply three accounting multipliers: sales, asset and EBIT and obtain similar results. We also find similar results with all measures, so we only report those based on using the sales multiplier to calculate excess value of a diversified firm. 
Empirical evidence shows that financial analysts' earnings forecasts convey important information to investors (Gonedes, Dopuch, and Penman (1976), Givoly and Lakonishok (1979), and Elton, Gruber, and Gultekin (1984)) for further discussion. Consequently, we apply a covered by analysts/not covered by analysts measure as an indication of information asymmetry. Firms with earnings forecast information available on the Institutional Brokers Estimate System (I/B/E/S) historical data tapes in the final month of the fiscal year are denoted as covered, while those with no available earnings forecasts are denoted as being not covered. The presumption is that firms covered by analysts reside in a lower information asymmetry environment that those not covered.

Table 1 contains descriptive information for the final sample of 27683 firm observations ( 38312 segments). The average number of segments per firm for the overall sample is 1.38 , while the average number of segments for multi-segment firms is 2.70 . The mean number of segments is 1.38 for both firms covered by analysts and those not covered by analysts. Average total assets and sales are much larger for multi-segment firms than for single-segment firms. Mean firm total assets and sales are approximately three times as large for firms covered by analysts than those not covered.

TABLE 1. Descriptive Statistics

\begin{tabular}{|c|c|c|c|c|c|}
\hline Characteristic & All Firms & $\begin{array}{l}\text { Single- } \\
\text { segment }\end{array}$ & $\begin{array}{l}\text { Multi- } \\
\text { Segment }\end{array}$ & $\begin{array}{l}\text { Not } \\
\text { Covered }\end{array}$ & Covered \\
\hline Number of observations & 27683 & 21268 & 6415 & 6227 & 21406 \\
\hline Mean number of segments & 1.38 & 1.00 & 2.70 & 1.38 & 1.38 \\
\hline Mean firm sales & 1192.38 & 864.41 & 2321.66 & 493.26 & 1436.71 \\
\hline Mean firm total assets & 1001.98 & 681.40 & 2105.85 & 375.28 & 1221.00 \\
\hline Mean segment sales & 842.64 & 864.41 & 767.68 & 378.40 & 1004.88 \\
\hline Mean segment total assets & 684.73 & 681.40 & 696.21 & 261.26 & 832.73 \\
\hline
\end{tabular}

Sample firms have total sales greater then \$20 million and with no segments in utility (sic code 4000-4999) and financial service (sic code 6000-6999). The sample includes 27683 observations from 1989 to 1998 . Not covered and covered indicate whether analyst forecasts of each firm's earnings are available in the last month of the fiscal year under consideration.

\subsection{Test Hypothesis and Empirical Results}

\subsection{Diversification and firm value}

We start with a confirmatory test that examines the relationship between diversification and the value of the firm. We first calculate the average excess value for the overall sample and the sample categorized by diversification. Although, some authors suggest that it is the difference in the line of operation rather than number of segments that characterize the essence of diversification, no studies actually show that the number of segments is an inferior diversification proxy to other suggested methods. Thus, in this study we classify firms as diversified if they report information for multiple segments.

The results in Table 2 show that the mean and median excess values for the overall sample are essentially zero. Similar to previous studies, the results also show that the mean excess value for single-segment firms is significantly greater than zero $(0.021)$ while the mean excess value for multi-segment firms is significantly less than zero $(-0.078)$. Further, there is a statistically significant difference between the mean and median values of the two groups. 


\subsection{Analyst Coverage and firm value}

Table 2 also contains average and median firm excess values for the sample based on financial analyst coverage. The sample is divided into those firms covered by financial analysts and those not covered. The average excess value for firms not covered is -0.206 , which is significantly less than zero. Covered firms have a mean excess value of 0.057 which is significantly greater than zero. The difference between the group means is statistically significant at the $1 \%$ level. Further, the absolute difference in mean and median excess values for covered and not covered firms is similar to the absolute difference for single- and multi-segment firms. This suggests that information asymmetry may have as great an influence on firm value as diversification.

TABLE 2. Excess Value, Diversification and Analyst Coverage

\begin{tabular}{|c|c|c|c|c|}
\hline & \multirow{2}{*}{$\begin{array}{l}\text { Number of obser- } \\
\text { vations }\end{array}$} & \multicolumn{2}{|c|}{ Excess Value } & \multirow{2}{*}{$\begin{array}{l}\text { Difference-in-means test } \\
\text { [Median] }\end{array}$} \\
\hline & & Mean & Median & \\
\hline All firms & 27683 & -0.002 & 0.000 & \multirow{3}{*}{$\begin{array}{l}\text { Single/Multi } \\
12.41^{*} \\
{\left[13.17^{*}\right]}\end{array}$} \\
\hline Single-segment & 21268 & $0.021 *$ & 0.000 & \\
\hline Multi-segment & 6415 & $-0.078 *$ & -0.091 & \\
\hline Not covered & 6227 & $-0.206^{*}$ & -0.215 & \multirow{3}{*}{$\begin{array}{l}\text { Not covered/Covered } \\
31.76^{*} \\
{\left[27.47^{*}\right]}\end{array}$} \\
\hline Covered & 21406 & $0.057 *$ & 0.028 & \\
\hline *Significant at & & & & \\
\hline
\end{tabular}

\subsection{Diversification, information asymmetry, and firm value}

Table 3 shows mean and median excess values for the sample divided by both the diversification and analyst coverage variables. The results show both variables affect value when examined simultaneously. Mean excess values are significantly smaller for firms that are not covered by financial analysts than for firms that are covered. Further, mean excess values for multiple-segment firms are statistically significantly lower than those for single-segment firms across all information asymmetry levels.

TABLE 3. Excess Value as Related to Diversification and Analyst Coverage

\begin{tabular}{llll}
\hline \multirow{2}{*}{ Analyst Coverage } & Diversification & & $\begin{array}{l}\text { Difference-in-Means[Median] } \\
\text { (Single/Multi) }\end{array}$ \\
\cline { 2 - 4 } Not covered & Single-segment & Multi-segment & $3.50^{*}$ \\
& $-0.192^{*}$ & $-0.252^{*}$ & {$\left[4.16^{*}\right]$} \\
Covered & {$[-0.195,4773]$} & {$[-0.273,1504]$} & $12.15^{*}$ \\
& $0.082^{*}$ & $-0.024^{*}$ & {$\left[12.60^{*}\right]$} \\
Difference-in-Means[Median] & {$[0.046,16495]$} & {$[-0.039,4911]$} & $13.84 *$ \\
(Not covered/Covered) & $28.54 *$ & {$\left[11.30^{*}\right]$} & \\
* Significant at the 1\% level. & {$[24.74 *]$} & & \\
The sample includes 27683 observations from 1989 to 1998. The significance of mean excess value and the difference-in-means \\
is measured using t-statistics. The difference in medians is tested using the non-parametric Wilcoxon signed-rank test for me- \\
dians.
\end{tabular}


The results clearly show that, on average, excess value is negative for non-covered firms. These firms apparently exhibit such high levels of information asymmetry that market participants subject both types to substantial valuation discounts.

\subsection{Regression Analysis}

Several studies suggest that there are factors that may affect excess value but are not necessarily determined by the level of diversification (e.g., Berger and Ofek (1995) and Denis, Denis and Sarin (1997)). Thus, to control for influences other than diversification and information asymmetry we estimate various regression models with excess value as the dependent variable. Similar to Denis, Denis and Sarin (1997) we include several independent variables to control for possible biases due to size (log of total assets), profitability (EBIT/sales), and leverage (total debt/total assets). We include Tobin's $\mathrm{Q}$ as suggested by other studies that relate the firm's growth rate to diversification. $Q$ is calculated as the ratio of the sum of the book value of debt plus the market value of equity and the book value of total assets. Additionally, as suggested by Lang and Stulz (1994), we control for the level of capital-constraint of the firm. We include both a dividend dummy, equal to one if the firm pays dividend, and zero otherwise, and the investment level (measured by investment capital/sales) in the analysis.

The effect of diversification is measured by the inclusion of a multi-segment dummy that equals one if the firm has multiple segments, and zero otherwise. Likewise, analyst coverage is represented by a dummy variable that equals one if financial analyst information is available for the firm, and zero otherwise. The possibility of a differential diversification effect for covered versus non-covered firms is addressed through the inclusion of a dummy variable denoted as multi*coverage. The variable is equal to the product of the coverage and multi-segment variables (i.e., the variable equals one if the firm is multi-segment and covered by analysts, and zero otherwise). If there is a diversification discount regardless the level of information asymmetry, the coefficient for the multisegment dummy variable should be significantly negative. Information asymmetry effects should be evidenced by significant coefficients for the coverage variables.

The regression results are shown in Table 4. In each estimated model, all control variable coefficients except that of the dividend dummy are statistically significant. Thus, we focus the discussion on the diversification and information asymmetry variables. In model 1 , only the multi-segment dummy is included with the control variables. As in previous studies, the coefficient is negative (-0.0704) and significant at the $1 \%$ level. In Model 2 the coverage dummy is included. The estimated coefficient for the coverage dummy is positive $(0.0635)$ and significant at the $1 \%$ level. In Model 2 the multi-segment variable coefficient is slightly smaller in absolute terms (-0.0648), but retains the same level of statistical significance.

In model 3, all previous variables are retained and the multi*coverage variable is added. In the regression, the estimated multi-segment dummy coefficient remains negative (-0.0293) but is now less than half its size in previous models. Further, the significance level for the coefficient falls to the $5 \%$ level. The coverage variable coefficient remains positive (0.0747) and highly significant. The multi*coverage coefficient is negative (-0.0497) and significant at the $1 \%$ level.

Overall, the regression results show that information asymmetry and diversification are significant determinants of firm value after controlling for other influences. The results indicate that information asymmetry explains a portion of the diversification discount since the inclusion of an analyst coverage variable reduces the absolute magnitude of the multi-segment dummy by over half. However, the multi-segment dummy retains statistical significance indicating that a significant diversification discount remains after controlling for the effects of analyst coverage. 
TABLE 4. Regression Tests on Excess Value

\begin{tabular}{llll}
\hline Variable & Model 1 & Model 2 & Model 3 \\
\hline Intercept & -0.7016 & -0.7183 & -0.7293 \\
Size & $(0.00)$ & $(0.00)$ & $(0.00)$ \\
& 0.0644 & 0.0572 & 0.0576 \\
Profitability & $(0.00)$ & $(0.00)$ & $0.00)$ \\
& 0.4051 & 0.4028 & $(0.00)$ \\
Q value & $(0.00)$ & $(0.00)$ & 0.2296 \\
& 0.2326 & 0.2297 & $(0.00)$ \\
Leverage & $(0.00)$ & $(0.00)$ & -0.1941 \\
& -0.2183 & -0.1954 & $(0.00)$ \\
Dividend dummy & $(0.00)$ & $(0.00)$ & -0.0014 \\
Investment level & -0.0015 & -0.0022 & $(0.85)$ \\
& $(0.83)$ & $(0.76)$ & 0.2555 \\
Multi-segment dummy & 0.2600 & 0.2561 & $(0.00)$ \\
Coverage dummy & $(0.00)$ & $(0.00)$ & -0.0293 \\
Multi*Coverage & -0.0704 & -0.0648 & $(0.05)$ \\
R-square & $(0.00)$ & $(0.00)$ & 0.0747 \\
\hline Regressions are estimated & 0.0635 & $(0.00)$ \\
\end{tabular}

Regressions are estimated using excess value as the dependent variable. The sample includes 27683 observations from 1989 to 1998. All test statistics are computed using White's (1980) heteroscedasticity-consistent covariance matrix. The p-values for each coefficient are shown in parentheses.

\subsection{Conclusion}

We use financial analyst coverage as a measure of information asymmetry to examine excess firm values associated with single- and multi-segment firms. We explicitly examine whether differences in information asymmetry can explain the previously documented diversification discount. Our results indicate that information asymmetry plays a major role in explaining the valuation of firms and that analyst coverage explains a portion of the diversification discount. However, a significant diversification discount remains after controlling for the effects of analyst coverage.

Acknowledgement: The authors gratefully acknowledge the contribution of I/B/E/S Inc. for providing earnings per share forecast data, available through the Institutional Brokers Estimate System.

\section{References}

1. Berger, P. and E. Ofek, 1995, "Diversification's effect on firm value,” Journal of Financial Economics 37, 39-65.

2. Comment R. and G.A. Jarrell, 1995, "Corporate focus and stock returns," Journal of Financial Economics 37, 67-87.

3. Denis, D., D. Denis, and A. Sarin, 1997, "Agency problems, equity ownership and corporate diversification," Journal of Finance 52, 135-160.

4. Dunn, K. and S. Nathan, 1998, "The Effect of Industry Diversification on Consensus and Individual Analysts' Earnings Forecasts,” Working Paper, Baruch College. 
5. Elton E., M. Gruber, and M. Gultekin, 1984, "Professional expectations, accuracy and diagnosis of errors," Journal of Financial and Quantitative Analysis 19, 351-363.

6. Givoly, D., and J. Lakonishok, 1979, "The information content of financial analysts' forecasts of earnings," Journal of Accounting and Economics 1, 165-185.

7. Gonedes, N., N. Dopuch, and S. Penman, 1976, "Disclosure rules, information-production, and capital market equilibrium: the case of forecast disclosure rules," Journal of Accounting Research 14, 89-137.

8. Graham, J. R., M. L. Lemmon, and J. Wolf, 1999, "Does Corporate Diversification Destroy Value?" Journal of Finance 57, 695-720.

9. Hadlock. C, M. Ryngaert and S. Thomas, 1998, "Corporate Structure and Equity Offerings: Are there benefits to diversification?" Journal of Business 74, 613-635.

10. Hubbard, R. G. and D. Palia, 1999, "A reexamination of the Conglomerate Merger Wave in the 1960s: An internal capital markets view," Journal of Finance 54, 1131-1152.

11. Hyland, D. C., 1997, "Why firms diversify, An empirical examination," unpublished doctoral dissertation, Ohio State University.

12. Krishnaswami, S. and V. Subramaniam, 1999, " Information asymmetry, valuation, and the corporate spinoff decision" Journal of Financial Economics 53, 73-112.

13. Lamont, Owen, and Christopher Polk, 1999, "The diversification discount: cash flows vs. returns," Journal of Finance 56, 1693-1721.

14. Lane D, M. Vikas and S. Ranjini, 1997, "Corporate focus and value creation evidence from spin-offs" Journal of Financial Economics 45, 257-281.

15. Lang, L and R. Stulz, 1994, “Tobin's q, corporate diversification, and firm performance.” Journal of Political Economy 102, 1248-1280.

16. Matsusaka, J. G., 1993, "Takeover motives during the conglomerate merger wave," RAND Journal of Economics 24, 357-379.

17. Myers, S. C. and N. S Majluf, 1984, "Corporate Financing and Investment Decisions When Firms Have Information That Investors Do Not Have," Journal of Financial Economics 13, 187-221.

18. Nanda, V. and M. Narayanan, 1999, "Disentangling needs: Financing needs, firm scope and diversititures," Journal of Financial Intermediation 8, 174-204.

19. Rajan, R., H. Servaes, and L. Zingales, 2000, "The cost of diversity: the diversification discount and inefficient investment, " Journal of Finance 55, 35-80.

20. Schipper, K., and R. Thompson, 1983, "Evidence on the capitalized value of merger activity for merging firms," Journal of Financial Economics 11, 85-119.

21. Servaes, H., 1996, "The value of diversification during the conglomerate merger wave," Journal of Finance 51, 1201-1225.

22. Shin, H., and R. M.. Stulz, 1998, “Are internal capital markets efficient?” Quarterly Journal of Economics $113,531-552$.

23. White, H., 1980, "A heteroskedasticity-consistent covariance matrix estimator and a direct test for heteroskedasticity," Econometrica 48, 817-838.

24. Wulf, J., 1999, "Influence and inefficiency in the internal capital market: Theory and evidence," Working paper, Wharton School, University of Pennsylvania. 
Notes 